\title{
Is capsule endoscopy effective for screening and surveillance of esophageal varices in patients with portal hypertension?
}

\author{
Kevin C Ruff and Virender K Sharma
}

Nature Clinical Practice Gastroenterology \& Hepatology (2009) 6: XXX-XXX [doi:10.1038/ncpgasthep1280]

\section{CORRIGENDUM}

In the Practice Point article by Ruff and Sharma published in the January 2009 issue of Nature Clinical Practice Gastroenterology \& Hepatology, the competing interests information was incorrect. The correct competing interests information should read "VK Sharma declared an association with Given Imaging. KC Ruff declared no competing interests.' VK Sharma is a Consultant for Given Imaging.
Published online

9 December 2008

www.nature.com/clinicalpractice doi:10.1038/ncpgasthep1318 